\title{
Navigating Evangelical Political Identity in the Era of Donald Trump
}

\author{
Anthony Comer ${ }^{1}$ and Laura Jacobi \\ Minnesota State University, Mankato, USA
}

\begin{abstract}
Evangelical Christians have always had a complex relationship with political issues in the United States, especially with the rise of the Christian right in the 1980s. Since 2017 the Trump presidency has amplified that complexity, presenting a new set of issues for consideration. With Festinger's (1957) Cognitive Dissonance theory and Tajfel's (1981) Social Identity theory as the foundation, this study examines how evangelical Christian pastors conceptualize their religious and political identities, and how they communicate with their congregants about political issues. Pastors act as crucial gatekeepers within their faith communities so they provide crucial insight into the evangelical community. Six pastors from a mid-sized, Midwestern university town were interviewed using a semi-structured format. Findings indicate pastors hold non-negotiable beliefs, distance themselves from political connotations of evangelicalism, and explain political values with religious values. When communicating with congregants, they reconcile competing values and respect differences but indicate their desire to follow God's convictions.
\end{abstract}

KEYWORDS: Cognitive Dissonance Theory, Donald Trump, Evangelical Christians, Social Identity Theory.

The term "evangelical" has taken on a political connotation within recent national dialogue, but the origins of the term are religious. To be an evangelical Christian means to spread the "evangel" or good news of Jesus Christ (FitzGerald, 2017). Religious evangelicalism is aligned with two consistent tenets: belief in Jesus Christ alone as a Lord and Savior and belief that the Bible functions as the inspired Word of God. Although these are religious beliefs, they carry over into how evangelicals approach the public square. However, since the Bible does not offer a guide on which political candidates to support, the idea of a truly "Christian" political identity remains open to interpretation.

Interpreting and navigating political identity is centrally important within the current study. Interpretation of political identity involves groups of people finding common values and stances on issues that unite them as a group. When groups navigate these identities, they search for practical ways of living out their common experiences and values. Although Christians throughout American history recognized that not every politician or political party would represent their interests one hundred percent of the time, they were still willing to take a chance that certain politicians and parties would represent those interests more comprehensively.

Many contemporary studies examine the awkward, tension-filled relationship religious groups have with political movements that imperfectly convey their values (e.g., Boerl, 2015; Hankins, 2008; Heltzel, 2009; Medhurst, 2017; Reed, 2019; Ribuffo, 2006; Salek, 2014; Smith,

${ }^{1}$ Correspondent Author E-Mail: tony.comer@mnsu.edu 
2016; Williams, 2018). Some scholars examined the unique tensions faced by evangelical Christians in the political realm. For instance, Smith (2016) examined how evangelical Christians wrestled with Mitt Romney (a devout Mormon) as a political candidate in the 2012 election. Many evangelicals overlooked their personal disdain for Mormon principles if they prioritized political conservatism. They were willing to overlook their religious convictions and band together to support Romney for the greater political good. Salek (2014) also examined how Romney relied on Franklin Graham, a prominent evangelical leader, during the 2012 presidential election to build credibility and win over the white evangelical base. Salek found that Reverend Graham encouraged these voters to overlook their objections to Mormonism by focusing on questions surrounding President Obama's faith. Additionally, scholars have examined how certain individual politicians navigate tensions between their political identity and religious identity. For instance, Reed (2019) examined the centrist politics of Anglican minister and former senator John Danforth. Reed examined how Danforth's political centrism and moral political leadership were shaped by his Anglican faith.

Some scholars have started to recognize the unique challenge a Trump candidacy and presidency poses for evangelical Christians (e.g., Margolis, 2019; Marti, 2019; Miller, 2019; Myers, 2019; Scala, 2020). For example, Margolis (2019) claimed that nominal evangelicals (evangelicals who only casually identify with their religion) supported Trump more than passionately engaged evangelicals. Marti (2019) drew attention to how Trump made the evangelicals feel. According to Marti, Trump convinced white evangelicals that their power base was threatened and that they therefore needed to support him in the general election. Miller (2019) questioned why prominent evangelical leaders like Dr. James Dobson and Dr. Wayne Grudem endorsed Trump even though they had blasted President Clinton's lack of moral leadership in the 1990s. Myers (2019) found that evangelicals voted for Trump in overwhelming numbers because of his strong stance on abortion. When evangelicals chose to support Trump for president, they risked opening themselves up to accusations of hypocrisy. Were they willing to support him in order to put pro-life justices on the Supreme Court and roll back laws in favor of abortion?

Scala (2020) found that many evangelicals supported Ted Cruz during the 2016 primaries but latched on to Trump during the general election and well into his presidency. In the Republican primaries, these voters who held strong religious beliefs were more apt to support Cruz. He used religious language and seemed to back conservative causes; he also lacked some of Trump's less appealing personal qualities. However, Cruz's campaign fizzled out, leaving Trump as the frontrunner. Evangelicals were left with a stark choice: support an imperfect candidate who imperfectly aligned with their values, or support a candidate who was antithetical to their values (Hillary Clinton). The evangelicals chose to support Trump. Similar to Scala's (2020) and Myers (2019) findings, Monk-Turner (2019) claimed that evangelical support for Donald Trump was shaped by their stance on gender culture war issues. Abortion played a huge role in evangelical support for Trump. When evangelicals coalesced around this issue, they were able to overlook his personal shortcomings.

Despite the potential for conflict between one's religious and political values, Holder and Josephson (2020) discovered that support for Trump by white evangelicals stayed strong during the contentious 2020 election. However, what happens when religious values clash with political values for evangelical Christian pastors who are in a position of influence and power as it pertains to religious and political identity? There is a paucity of research on how evangelical Christians navigate tensions between their religious and political identities and an especially large gap in the literature upon how evangelical religious leaders navigate such tensions. This study aims to contribute to a deeper understanding of how evangelical Christian pastors reconcile conflicting 
religious and political beliefs. With this aim in mind, the following research questions were advanced:

1. How do evangelical Christian pastors attempt to understand and explain their religious and political identity?

2. How do evangelical Christian pastors handle conflict between personal religious and political opinions and beliefs in order to communicate with their congregations?

\section{Literature Review}

The complicated relationship of evangelical Christians with Trump is examined along with two theories that help to provide a theoretical foundation for the purpose of understanding the religious and political identities of evangelical Christian pastors and the conflicts faced between them in the Trump era. Tajfel's (1981) Social Identity theory provides a lens to examine the ingroup/outgroup mentality of evangelical Christians. Festinger's (1957) Cognitive Dissonance theory provides a lens through which to examine tensions between evangelical political and religious identity.

\section{Christian Political Identity and Trump}

Ever since Donald Trump announced his campaign for the presidency in 2015, evangelical Christians have had a complicated relationship with the $45^{\text {th }}$ president of the United States. Brown (2015), an evangelical theologian, criticized the Trump agenda. Citing concerns about Trump's language and demeanor, leaders like Brown cautioned evangelical Christians against embracing his agenda even though he seemed to promise conservative reforms. Many Christians maintained a skeptical attitude towards Trump, embracing him only as an alternative to Hillary Clinton in the general election when all other candidates had failed. When it became clear that the new president was going to execute a pro-life, pro-traditional marriage agenda unexpectedly, many evangelicals were quick to rally behind him as a surprising source of hope. However, Brown cautioned evangelicals not to put all their political eggs in the Trump basket because he still displayed immature and often vulgar behavior. Although evangelicals were not as quick to turn around and embrace Trump's personal behavior upon election, on an agenda level the message was largely "fall in line" or leave the evangelical camp. Although Trump was a surprise champion and standard bearer of the supposed evangelical Christian agenda, he was nonetheless a standard bearer, and dissent was treated as a wholesale rejection of the conservative movement and a narrative agenda of reclaiming America for God. The deeply resonating nature of such an agenda of reclaiming lost hegemony produced a burden within evangelicals. Although he could prove to be an objectionable leader at times, the risk of withdrawing support from his cause was too great.

Scholars Harris and Steinler (2016) saw a different, darker reality within contradictory evangelical support for Trump, arguing a sort of "give-take" relationship. If evangelicals bowed to Trump's agenda and offered uncritical praise, then Donald Trump would restore their dreams of a white hegemonic structure of power in the United States. Harris and Steinler claimed that Trump has presented evangelicals with a chance to reclaim white hegemony previously lost during the Obama years and join in with the Make America Great Again agenda. Because of Donald Trump's strongman personality and his promise to fight for traditional evangelical values (pro-life Supreme Court justices and traditional marriage) many evangelical leaders overlooked his repugnant personal qualities (misogyny, tweeting, racism, etc). Restored traditional Christian values fused 
with the MAGA agenda to create a supposed holy alliance between evangelicals and the Trump presidency.

Evangelicals expressed their ability to overlook Trump's negative personal qualities (the immature tweeting, divorces and other reprehensible personal qualities) for some perceived greater good. According to Lakoff (2017), embracing the Trump phenomenon meant embracing a worldview with no central set of principles, merely the embrace of his ego. However, evangelical Christians could gain access to his ego and use it for their own purposes. The naked embrace of political power for the sake of a supposed "greater good" is exactly what Marsden (2007) warned about during the Bush administration. He warned that this would result in compromising a Christian witness of love and faith before the watching world and equate Christianity with an agenda of partisan bitterness and division. At the end of the Bush administration, evangelicals in the United States were left with a crucial question of how they would embrace politics going forward. They needed to figure out how to relate to power and what issues they would emphasize as a political movement. However, throughout history, their shared social agenda had driven them forward as a group to make difficult choices through many tumultuous times.

\section{Social Identity Theory}

Originating in the field of social psychology, Tajfel's (1981) Social Identity theory (SIT) explains how groups find common purpose and unify around issues, functioning as "in-groups." The theory has been used to examine group identities across multiple disciplines (e.g., Burford, 2012; Choi, 2017; Constantine, 2017; Davis et. al, 2019; Gundlach, 2006; Hogg, 1995; Onyalla, 2018). SIT can also be utilized to examine how evangelical Christians function as a political group and make decisions to support political candidates or movements. Rather than supposing that groups are composed merely of individuals who choose to affiliate with other individuals, SIT examines human beings as members of groups who are influenced and controlled by the behavior, beliefs and ideology of the groups themselves. The creation of a common set of values for a group (i.e. the support of a political candidate or cause) differentiates in-groups from out-groups. This theory is particularly important because evangelical Christianity is composed of several sub-groups with common political goals. Group members need to feel a sense of belonging or "identification" with their ingroup, and this influences how they interact with other groups. The group is not merely a source of meeting emotional needs or providing structure. Tajfel and Turner (1982) propose that the social group literally explains an individual's source of identity, which is important because it may help scholars understand why evangelical Christians feel pressure to support certain political candidates or causes.

SIT provides a theoretical lens through which to examine evangelical Christian support for Trump in the 2016 presidential election. The evangelical Christians supported Trump not because of his character (which many Christians no doubt found reprehensible) but because of his stance on certain social issues (e.g., abortion and gay marriage). They found themselves supporting his message and movement despite the shortcomings of the messenger. SIT may help to explain why this choice was made.

Tajfel's theory can be readily applied to the contemporary American political and religious landscape. According to Nicholls and Rice (2017), social groups construct norms and a sense of guiding community. Although Nicholls and Rice viewed this in the context of online groups, highlighting these points is also important regarding evangelical political identity. Political norms can provide guidance and structure for the in-group (i.e. evangelical Christians). For instance, it might be normative for Christian leaders to encourage their congregants to "fall in line" and support Republican candidates and positions during elections. This clearly represents Tajfel's (1982) notion 
that groups work together and function along homogenous lines as a method of maintaining ideological purity within the dominant group as the group interacts with outsiders.

\section{Cognitive Dissonance}

Festinger's (1957) Cognitive Dissonance theory (CDT) is another theoretical lens through which to examine the phenomenon of evangelical support for Trump. According to CDT, people experience anxiety or "dissonance" when they are forced to navigate conflicting beliefs that they hold. The theory examines competing and often contrasting views people hold on various issues (Anderton, 2011; Bolstad, 2013; Burns, 2006; Glatz, 2012; Gruber, 2003; McGrath, 2020; Smith, 2016; Vaidias, 2019). For instance, using CDT, Glatz (2012) explained parental reactions to adolescent children with an alcohol addiction. Bolstad (2013) investigated voting choices of the American public through the lens of this theory. More relevant to the current study, Smith (2016) researched evangelical Christian acceptance of Mormons as "Christians" despite their questionable theological beliefs; the study examined whether Christians were willing to overlook their beliefs in the theological realm (of Mormons not being full-fledged Christians) and hold their support of Romney higher for the sake of political identity and the 2012 election. The same question could be posed to evangelical Christians who supported Trump in the 2016 election. On the one hand Trump was not seen by white evangelical Christians as representative of Christian values in society. However, holding political identity as priority over religious beliefs helped evangelicals to reduce any dissonance. Although some perceived Trump as someone who did not possess the character to hold the highest office of the land, many evangelicals reluctantly supported Trump when the only other choice was supporting Democratic challenger Hillary Clinton. As Long (2016) notes, they believed they were choosing "the lesser of two evils." In exchange for voting for Trump and supporting him, perhaps they would accomplish some of their major goals as a group. Evangelicals and Trump developed a reciprocal relationship.

The nature of conservative identity must be considered in order to truly understand why Trump's call for conservative support resonated so deeply with Christians during the 2016 election. Examining the strong-held nature of this belief will also help scholars understand how holding two important beliefs in tension (Christian identity versus conservative political identity) can cause cognitive dissonance amongst evangelicals. In other words, how do evangelical Christians navigate their priorities when religious beliefs clash with political beliefs?

\section{Author Context}

\section{Tony}

As an evangelical Christian, I grew up believing faith was an important part of life. I would have said I believed that the Bible was without error in dictating how human beings should live and act. In my adult life, I served in a small congregation as an evangelical pastor. In the aftermath of the 2016 election, I saw how evangelical Christians gave robust support and defense to Donald Trump and continued to fight an age-old culture war over Christian values. Their faces were in my mind as I set out to understand how evangelicals can navigate the dissonance between their political and religious values. 


\section{Laura}

Growing up on a strict conservative religious family, I watched my parents and extended relatives wrestle with conflicts between their religious and political values. The political candidates they supported often "failed" on moral grounds, and I was fascinated with how family members often justified the behavior of favored politicians if and when such politicians showed promise to support specific agendas (i.e. end abortion). It is with such a background that I came to this project with great interest in exploring how political and religious identities intersect and conflict and how individuals navigate such conflict and dissonance.

\section{Case Trustworthiness}

As investigators into a newer area of research, we reflected upon Lincoln and Guba's (1985) factors of case trustworthiness: confirmability, credibility, transferability, and dependability. While our backgrounds and experiences certainly influence our interest in the topic, we made a conscious attempt to remain neutral throughout the research process - from data collection through analysis, and to allow the participants' words to speak for themselves. In this way, we attempted to ensure some level of confirmability (i.e. degree of neutrality) in order to obtain credibility (i.e. confidence in the truth of the findings). Because group dynamics support fundamental aspects of Social Identity theory in many contexts, and because cognitive dissonance has been shown applicable in many settings, we expected the same results in the context of our study, suggesting transferability. As a pilot investigation into a topic that is not well-researched, dependability (i.e. findings can be repeated) may be best addressed in future studies.

\section{Methods}

\section{Recruitment}

Upon approval from the Institutional Review Board, the researchers used convenience sampling in identifying and recruiting local evangelical Christian pastors in a rural Midwestern town. Via email, the researchers invited pastors to participate because their congregants were largely conservative individuals who tend to vote Republican and feature a more prominent focus on religious and moral issues. Six pastors expressed interest.

\section{Participants}

The researchers interviewed six pastors from a rural Midwestern town. Denominations of the pastors varied from conservative to liberal. Participants included one Baptist pastor, two Pentecostal pastors, one Covenant church pastor, and two non-denominational pastors. All six participants were male, aged 40-65. Five participants were white, and one was African American. Although participants all came from the same town, they each pastored different churches with different backgrounds, traditions and practices. These differing traditions revolved around interpretations of theological tenets and denominational preferences. 


\section{Data Collection}

To ensure the comfort of participants and to maintain confidentiality, pastors were interviewed in their offices. The researchers used Wengraf"s (2001) approach during the interview; while keeping the research questions at the center of the interviewer's process, the approach allowed room for follow-up questions to dig deeper when necessary. In order to understand how evangelical Christian pastors, navigate their religious and political identities and avoid dissonance with potential conflicts between them, researchers asked the participants questions about their own religious and political beliefs and how they guide their local congregations through complex, difficult political topics. Sample questions included "Do you identify as an evangelical Christian? What does that term mean for you?"; "In what ways do you believe the Bible should be a guiding authority in the political affairs of American voters?" and "How do you portray political viewpoints and guide your congregation in political conversation today?"

\section{Qualitative Content Analysis}

Following data collection, the researchers recorded and transcribed interviews. They used the approach of Elo and Kyngas (2007), which involves open coding, categorization, and abstraction. During open coding, the investigator read and re-read the transcripts while searching for common themes. They categorized the information when they discovered groups of commonalities within the data. For instance, consistent discussion of "values" led the researchers to mark to that as a category. Finally, during the abstraction phase, they combined the data into larger categories using "content-characteristic words." (Elo \& Kyngas, 2007, p. 111). Contentcharacteristic words were words used by participants themselves. For instance, pastors talked about not giving space for division in their church services. Echoing this theme, many pastors reiterated the point with similar language (i.e. "putting up picket fences" and "don't bring the split"). The researchers grouped such language together under one large theme. These types of terms indicated the same theme of not giving space for division.

\section{Results}

Results are discussed below as aligned with the research questions: how the pastors interpreted their religious and political identities and how they handled conflict between personal religious and political opinions and beliefs in order to communicate with their congregations.

\section{RQ 1: Conceptualization and Clarification of Religious Identity}

Participants clarified their religious and political identities in the following ways: explaining non-negotiable beliefs an evangelical Christian must hold, distancing themselves from the modern political connotation of the term "evangelical," and explaining their political values based on religious values.

\section{Evangelical Pastors Hold Non-negotiable Beliefs}

Participants stated some non-negotiable evangelical beliefs which would make or break their identity as an evangelical. For example, after referring to some disagreements on minor issues, one participant emphasized these non-negotiable beliefs as "close-handed issues": 
We differ some in the way that some evangelicals would look at some of the gifts . . . but for the most part more the close-handed issues uhm... the Trinity, you know, God the Father, God the Son, God the Holy Spirit, you know a lot of the foundational things that are kind of we call them nonnegotiables.

It was common for participants to define their evangelical identity with a series of distinguishing beliefs. For instance, one participant emphasized the importance of a personal relationship with Christ:

What distinguishes evangelicals from all other faith denominations is... membership to a church is more important to them than really having a relationship with Jesus Christ. As evangelicals we believe in having a personal relationship with Jesus Christ and not necessarily... having connection with a church that makes you a believer or a Christian.

For this participant being an evangelical meant a "personal relationship" or experience of knowing Christ rather than just belonging to a church; this put the term evangelical in a subjective realm of experience. Other participants emphasized the theological tenets of an evangelical. One participant claimed to be "someone who believes that the Word of God is... infallible" and that it "communicates what God wants us to know ... we can depend on it, rely on it, base our lives on it, our worldview on it." For this participant, the infallibility of God's Word served as a nonnegotiable belief. Rich in theological connotation, the word "infallibility" implies that the Bible is the totally perfect, literally inspired Word of God with no mistakes in meaning as passed down throughout the centuries. This participant believed that Scripture is a perfect vessel through which God communicates "what God wants us to know."

While not every pastor gave a categorical list of religious doctrines an evangelical Christian must believe, one participant gave a consistent, historically accurate list:

We believe in...The God the Father, the Trinity would be God the Father, God the Son, God the Holy Spirit. We believe that the church is God's idea and being part of the church is, is a commendable thing that the Bible instructs, and we believe that the Holy Spirit guides and leads the believer. The Bible has final authority in everything we do, and Jesus Christ is Lord of our lives, and that His example is what gives us the reflection of how we should live.

This participant listed several non-negotiable beliefs most conservative Christians have believed to be true over the centuries: a belief in a literal, personal triune God and a belief that God is revealed through the Bible. These ideas in the theological realm shaped a strong, robust evangelical identity for the participant.

In reflecting upon the word "evangelical," a final participant reflected on "a desire to hold the true Biblical worldview and... try to live and govern a church so to speak according to the ways of the Bible." The term "worldview" came up in this answer. The mission for the evangelical was to "try to live and govern" according to a Christian worldview which could be found in unswerving loyalty to Scripture. Inherent in the terminology of "worldview" was a belief that the Scriptures are again an infallible guide relevant and applicable to life in the $21^{\text {st }}$ century. 


\section{Evangelical Pastors Distance Themselves from the Political Connotation of Evangelical}

When it came to the traditional theological definition of evangelical Christian, the pastors unanimously assented and agreed to being called an evangelical. However, many pastors lamented the political connotation that has arisen particularly within a North American context, aligning the term evangelical with Trump voter or right-wing voter. One participant remarked for instance that he would not define himself as a Liberty University evangelical or religious right evangelical. Many participants believed that this form of evangelicalism had been recklessly tied to a form of nationalism which put American identity on the same level as faith identity. For instance, one participant said

I grew up in a very conservative Baptist setting and you know, evangelical meant about 82 different things; at least there's a list of 82 things you had to adhere to. I think if someone were to say are you an evangelical in a Liberty University or Religious Right way, I'd say naw, that's not the evangelical of Scripture.

An interesting tension comes up in this statement, pitting the "Liberty University" or "Religious Right" evangelical against the "evangelical" of Scripture. In this participant's mind the LU or RR evangelical was an overly politicized evangelical, and the participant seemed to believe this was an errant interpretation.

With a similar sentiment, another participant lamented the politicization of the term evangelical. This participant was comfortable identifying as a theological or religious evangelical but went on to say:

But politically that term has... come to mean something that uhm I'm not sure I would love to stand in the midst of that group. CNN, MSNBC, Fox's talk about evangelicals--I don't know that often when they're talking about that's the group I would place myself with.

Echoing the quote from the previous participant, this participant saw mainstream media caricaturing evangelicals and claiming they represent something with which this participant was not comfortable identifying. The participant seemed to have a difficult time accepting the political definition attributed to evangelicals in the current political environment. Listing the news media networks like CNN and Fox might provide another clue to the participant's meaning since these networks may provide a biased interpretation of a group rather than one that is factually based. The participant likely did not want the term "evangelical" to define him according to the overgeneralized and sometimes inaccurate viewpoint of the American news media.

\section{Evangelical Pastors Explain Political Values with Religious Values}

Participants also emphasized the connection between strongly held religious identity and political identity. One participant summed it up best, saying: 
I'm not a politician... but it seems to me that conservatives are working to conserve what we have, of what we own. That's why I think you see building a wall is to protect us and to conserve what we have. Liberal has to do with sharing. In a way what we have with others, trying to find a way to help others. So liberal politically can mean that. In a theological framework conservative has come to mean an adherence to the Word of God and by and large; it has also become identified with what I would call overly literal interpretation of the Scriptures, which has been in many ways legalism.

This participant's acknowledgement "I'm not a politician" was followed by a frank attempt to interpret conservatism and liberalism by a broad set of values (conserving versus sharing). An intriguing tension emerges here because one of the social values set forth by Jesus and the first century church was the value of sharing with others. According to this participant's definition, political conservatism appears to be diametrically opposed to Christian values.

Participants continued to emphasize that conservatives and liberals were best identified by the beliefs they held. Holding a certain set of beliefs was at the core of what it meant to be a "conservative" or "liberal." They were not defined by the clothes they wore, the houses they lived in or any other outward sign. Instead, they were clearly distinguished by their beliefs and how they gave those beliefs expression in the world around them. For instance, one participant said:

Conservative I think generally, to conserve small government... Small government authority over our lives, that the government should largely kind of you know live and let the people do their thing... Liberal I think in its healthiest form to stand up for the subgroups that um maybe because of culture and society and whatever else get left over.

This participant zeroed in on the ideas or general principles found in conservatism or liberalism, identifying conservatism with "small government" and liberalism with a progressive ethic of inclusion and protection for minorities. Although these were not necessarily specific policies, they were foundational worldview presuppositions which would shape how conservatives and liberals thought and acted upon specific policies. For the participant, these ideas served as a springboard from ideas to action.

Another participant saw the tension between conservative and liberal identity in terms of what these two groups believed. But this participant could not as quickly and neatly differentiate between the two:

When I was very conservative, I could tell you what liberal was because it was the things I disagreed with . . . if there's been times in my ministry where I've tended on the left of center it's easier to say what conservative is because it's what I disagree with.

This participant defined the terms conservative and liberal in tension with one another, saying he could easily define conservative because it was what he disagreed with. However, this participant was able to clearly state what he was and was not when he held those previous beliefs. When he was a conservative, he could clearly pinpoint what the other side believed and why it was wrong because he was forced to take a stance against it. Being forced to take a stand for something or against something helped reinforce ideological dividing lines for participants. They were able to define what they stood for as they understood and communicated what they were against. However, 
this same participant also admitted the lines blurred when he moved towards the center and away from being completely conservative or completely liberal.

The correlation between a theological and political conservatism and liberalism was often seamlessly integrated. Participants saw conservative policies and (Republican policies particularly) as compatible with a Christian worldview while some participants were hesitant to state that liberalism could be compatible with the Christian worldview. One participant expressed a belief that the conservative/liberal divide was more complicated than it sometimes seemed:

Sometimes if you align with more of a conservative view, there's elements with the conservative view that on the surface is like "Oh! It's straight Biblical" But then there's some underlining things that are tremendously unbiblical that are not necessarily seen. But then with the liberals you say "Liberal, man it seems very, very unbiblical." But then there's some underlining things that are tremendously Biblical things on the liberal side of things.

This participant noted that it was difficult to condemn one side and heap unqualified praise on the other. Instead, both sides of conservative and liberal political conversation had elements of good and bad to them. But not every pastor saw these issues as gray. Instead, one participant drew on Biblical imagery to describe conservative versus liberal:

I just think it just is... just so dangerous because it's a wide road, it's a broad road, it's a destructive road. And uhhh... that term just fits in government too. Liberal is, I don't know. I just... they both have just really mirrored one another...

Describing liberalism as a wide road drew back to imagery Jesus used. According to the words of Jesus, the broad road would lead to destruction and the narrow road would lead to life. By using this comparison this pastor claimed the excessive permissiveness of liberalism would harm the church and the political sphere. According to this participant, safety and security (freedom from danger) lay in following the conservative, narrow road.

In summary, participants conceptualized their identity by identifying with non-negotiable beliefs, distancing themselves from the political connotation of the evangelical label and embracing conservatism. These factors helped shape how they communicated their identity.

\section{RQ 2: Communicating with Congregants}

Participants also discussed how they communicated with their congregations about controversial political issues. To communicate with their congregations, pastors first reconciled their own competing values and then encouraged their congregants to respect differences of opinion but follow God's convictions.

\section{Evangelical Pastors Reconcile Competing Values}

To reconcile competing religious and political values, participants appeared to allow one to take precedence over another. Some participants focused more heavily on religious values in framing their political values. For example, one participant reconciled competing values by pointing to Trump's lack of character as a reason for not supporting him: 
Look at his character. I would say the guy has some clouds of smoke all around him. You've got people close to being indicted; you've got all kinds of issues. You've got issues of immorality. He himself has confessed to all of these, you know relations with women. You learn a lot about his character from how we treat one another; it seems to be he seems to degrade women and all of these poor people, every turn.

This participant believed Trump had degraded the character of the conservative movement and could not function as a representative of conservatism because of his character and language. He was unable to embrace the Trump presidency like some evangelicals because he held certain values (or "character") too highly and believed the Trump administration violated those values. The participant held to certain criteria deduced from his faith and believed a president's character would reveal whether he would be an effective leader. This participant reconciled competing values by judging Trump according to his religious beliefs. Echoing the same theme, another participant said:

Trump getting elected... I mean what does that say to us that somebody who is so morally not the leader that the evangelical would choose as a leader. Does that say that those two things are still at the center for them and they don't care what type of leader they elect as long as those two things stay true? I don't... I'm asking a question. I don't know that I have an answer because I think the character that I see in our president is so antithesis to the character of Christ.

Again, the character question came into play. By pointing back to Trump's lack of character, this participant put up clear boundaries. This participant would support a candidate who was a great moral leader. However, noting that Trump was "somebody who is so morally not the leader that an evangelical would choose," he asks if voters who supported him were able to overlook a balanced focus on morality because he gave them what they wanted on abortion and gay marriage. In the harshest terms possible, the participant said Trump's character is the "antithesis to the character of Christ." In this case the participant valued the "character of Christ" and judged Trump's character in relationship to it. He reconciled competing values by holding the character of Christ as the standard and judging politicians according to the standard.

Other participants weighed political values more heavily when reconciling competing values and focused on what Trump would do for society as a result of God's will. For example, one participant concluded that Trump must be an "instrument sent by God for something":

Boy I'll tell ya, um, he's not a politician. He's not a politician and I think that's what's so awkward to deal with because he's not a politician. He's not even the most skilled at using some of his narrative and things he says and the way he says them, that type of thing. But I believe despite all that I really believe that he's an instrument sent by God for something.

This participant noted that Trump was an imperfect vessel for God's plan. However, this participant believed that he was "an instrument sent by God" for a divine purpose. According to this participant, any of Trump's myriad of flaws did not disqualify him from being an instrument of God, with a special, divine purpose. Although this participant was not sure of the specifics of this purpose, any invocation of a divine purpose would set his presidency above any criticism. The 
participant was able to justify Trump's behavior and make sense of his presidency by pointing back to the mysterious "will of God."

Another participant handled conflicts between political and religious identity in a similar manner:

When you look at all the trails economically and the things I valueeconomics and morality I see that he has done a tremendous job. It's just that people undermine if they don't believe in and agree with what he's saying and what he's doing. And he's just trying to protect the nation from destroying itself. People don't like that.

According to the participant, Trump exerted strong leadership in revitalizing the economy and reviving morality. This made him a strong leader who was criticized merely for leading and protecting the people of the United States. The same participant also pointed out that he was winning a crucial culture war by making it acceptable to say "Merry Christmas" during the holiday season again. According to these religious values, Trump represented the beliefs of these pastors.

Participants handled differences between their political and religious values by giving precedence to one over the other. Although they believed their political and religious experiences were both important, they reconciled these opposing experiences by making difficult choices.

\section{Evangelical Pastors Encourage Respect of Differences while Following God's Convictions}

Pastors wanted congregants to respect varying political beliefs, however, they emphasized following God's convictions, and oftentimes, this had political undertones. For example, one participant stated, "I think that the very thing that we think is weighty to God and heavy and really important, I think we might miss it . . . there's some things that we really need to dig into the Scriptures more and pray about to really see what the heart of God is." He calls on his congregation to examine their hearts and see if they are really getting at the core of God's priorities for a good and just society. This participant perceives that Christians should look to God's priorities, which can be unlocked through Bible-reading and prayer.

Although participants did not directly encourage their congregants to support certain issues or candidates, they certainly carried influence by indicating that church members should consider where God leads them. For example, when participants were asked how they would respond if different members of their church pressured one another to support certain political candidates over others, one participant stated:

Six months ago, I really was very direct about the political climate that we live in, and I brought people back to the Word of God and what God says. What does God want us to do? That way nobody in the congregation goes well "I'm leaning this way" or "I'm leaning this way" No, like I'm leaning towards God... whatever direction God leads me towards because of ... my convictions, and my Biblical beliefs, and that's a direction I go, not going this direction and trying to make God agree with what I decide to go with.

Another pastor expressed a very similar sentiment by suggesting that "those who are leaning into the scriptures for guidance should find guidance from that." The implication of these pastors' statements is that political motives should be derived from religious beliefs. In a sense, 
this takes voting decisions out of the hands of congregants because they should be relying on God and scripture for decisions surrounding political actions.

In some cases, participants perceived that God's will was to not allow space for division. Therefore, they were unwilling to let political controversies dominate the agenda of their Sunday morning gatherings or their focus as a community. One participant said:

I probably just don't give a lot of space for it. People can get riled up but it's not something we will take a strong stance on. Whether it's abortion... my personal feeling is a strong "this is probably the most immoral thing that has been allowed to happen in our nation... " that being said I've wrestled with again do you put up more walls by making that stance?

This participant saw an unnecessarily divisive bold stance as something that would potentially put up more walls and do more harm than good. Another participant said, "I guess you got to continue to put up those picket fences and just keep those unnecessary divisions out the best you can without being... controlling, judgmental, weird." Ironically, by putting up "picket fences," this pastor determined what topics were addressed or given priority. He controlled the messages given in church despite his concern about being perceived as "controlling, judgmental, weird."

Another participant argued that the church should not split or bring division but instead focus on Jesus as the central decision-maker:

It's important that we understand what we are dealing with as a church that we don't bring the split. We would rather bring people together and preach the gospel to them and let them know that Jesus will not behave like that, even if we disagree on a particular subject. It doesn't have to undermine what the Scripture says. What would Jesus do? That's the question we ask.

This participant points out that unnecessary divisions should not be at the center of a Christian's mind while also conveying that Christians should always consider how Jesus called them to act. Although the direct statement is that political issues are secondary, the underlying message is still that congregants should rely on God for all decisions they make, including political ones.

\section{Discussion}

Interviews yielded salient themes relevant to participants' evangelical identity and how they communicated about political issues to their congregations. Evangelical Christian pastors strongly identified with certain non-negotiable evangelical beliefs and resisted political connotations of the term "evangelical" but often explained political values based on religious values. In communicating with congregants, pastors reconciled their own competing values and then encouraged their congregants to respect differences of opinion but also follow God's convictions. Examining these themes through the lens of Social Identity theory and Cognitive Dissonance theory offers valuable insights. 


\section{Social Identity Theory}

Social Identity theory explains that an ingroup/outgroup mentality can give common purpose to groups and guide individuals in making important decisions and forming opinions about valuable issues. In this case the political and religious identities of pastors were influenced by their participation in social groups (local church congregations in this case). However, it is also clear that pastors utilized their position within their congregations to shape the in-group.

Certain evangelical beliefs shaped how these pastors thought about their involvement in faith community (the church) and society at large. For instance, a pastor might believe that the Bible is the inerrantly, inspired perfect Word of God and the final authority for moral matters. This same pastor would then cite the Bible as his or her reason for supporting a certain set of moral values in interactions with other people. This pastor would also encourage members of his or her community to the same set of values based on interpreting the Bible.

Tajfel's SIT can help make sense of how Christians identify in their churches, framing this identification as part of the process of interpretation. The term "evangelical" served as a form of social identity for these pastors. Confirming previous research by Nicholls and Rice (2017), which suggests that social groups construct norms and a sense of guiding community, participants in this study identified as evangelicals according to a series of set beliefs, and these beliefs in community with one another shaped how they interpreted all of life, including how they sought political interpretation. Again, these pastors saw themselves first as ministers of the gospel. Although these beliefs were deeply personal, they were not private. Their definition of evangelical stemmed in certain theological beliefs but branched out to shape how these pastors thought about politics and communicated about politics. One pastor leaned on the book of Genesis to describe how he believed the world was originally set up. Drawing insight from the biblical origin story, he was then able to reach the conclusion that this origin story communicated God's intentions for society. This participant was able to carry his theological beliefs (grounded in the book of Genesis) into the world around him. He carried certain theological beliefs into his everyday living and beliefs about how people should act towards one another. This language was phrased as creating a culture of human flourishing because this participant saw a culture of human flourishing in the book of Genesis. Although this is one specific example, this process of theological interpretation took place in many other ways with many participants. They were able to draw beliefs from the Bible and their theological tradition and bring those into interpretations of current events.

As revealed in SIT studies conducted in other contexts (e.g., Burford, 2012; Choi, 2017; Davis et. al, 2019; Gundlach, 2006; Hogg, 1995), participants in this study did not merely rely on their own interpretation to understand and navigate their religious and political identities. They also relied on their evangelical groups for mutual interpretation. The "social" aspect of such mutual interpretation showed up in how evangelical pastors rely on their congregations to validate or reject what they teach from the Bible on any given Sunday. Most pastors started with the foundational belief that the Bible is the inspired Word of God. After all, this is part of the definition of an "evangelical." Believing certain things to be true about the Bible is part of what makes a Christian part of the "evangelical" sub-group. Participants generally check in with other sources to make sure their interpretation of the Bible is correct. For instance, a pastor might also turn to a respected evangelical commentator to make sure their interpretation squares with orthodoxy. Also, evangelical pastors face certain pressures to conform and not dissent from their sub-group of Christianity. Certain sets of assumptions held by the group about the Bible might be encouraged and not discouraged.

Pastors also used their position within the group to influence members of their social group. They often talked in terms of controlling or filtering what was discussed during Sunday morning 
services and in their faith communities. One pastor mentioned not allowing room for division and "taking away the voice" of people who tried to stir up such division. They had the ability to allow space or not allow space for talking about divisive and difficult political issues.

Another example of pastoral influence within the evangelical Christian social group was how many pastors encouraged their congregants to vote. One pastor mentioned that they did not tell congregants exactly what ideas to vote for or which candidate to support. Instead, pastors espoused certain values and encouraged congregants to think according to a conservative evangelical interpretation of the Bible. Pastors did not indicate that they told their congregants to support Republicans, Democrats, or Independents. Instead, they encouraged their congregants to champion certain issues when they went to the ballot box. For example, one pastor encouraged his congregants to think about "God's original intent" for life and marriage. He encouraged participants to vote for the candidate which best represented God's original intent for life and humanity.

Finally, pastors used their influence to encourage critical thinking about difficult, controversial issues. While pastors did not directly tell congregants what conclusions to draw, they encouraged them to think about these issues and viewed themselves as fair arbitrators of such issues. One participant used the example of encouraging an African American pastor friend to share about police brutality at church. Another participant explained how he encouraged participants to take a compassionate stance towards public officials by praying for both Donald Trump and Nancy Pelosi at the height of the government shutdown in January 2019. Although these pastors were not concerned about eliciting particular viewpoints from their congregants, they were concerned about encouraging them to think about such issues in a nuanced way. They used their leadership positions to make room or not make room for such issues. Although the pastors did not allow space for division, they did often make space for intentional conversation in the group.

\section{Cognitive Dissonance Theory}

Cognitive Dissonance theory examines how individuals resolve competing or discrepant information, including political and religious values. In this study, participants faced cognitive dissonance any time they confronted a political versus religious values divide. In every case the participant was asked to overlook a certain set of objections in order to voice support. For proTrump participants they were asked to overlook his inflammatory rhetoric in order to stay in line with his pro-life and traditional marriage agenda. However, anti-Trump participants were asked to stand against Trump and his agenda in support of "not compromising" and speaking truth to power.

Some participants handled the cognitive dissonance by emphasizing the significance of certain issues but not directly telling congregants how to vote. Many pastors only talked with their congregants about political matters in terms of telling them about the importance of voting. In this way pastors were safeguarded from accusations that they were telling congregants how to vote.

As conveyed in previous research, individuals often "choose" one "side" in order to compensate for the cognitive dissonance they experience; for example, Smith (2016) found Christians overlooked their theological beliefs in order to support a Mormon, Mitt Romney, in the political realm. Smith's finding was confirmed in this study, in which at times, pastors indirectly wielded political influence over their congregants by emphasizing certain issues above others (i.e. abortion and homosexuality). By emphasizing these issues as overarching "moral concerns" they sometimes unintentionally de-emphasized other issues, giving believers permission to support a candidate who took a strong stance on the more important issues. For example, despite Donald Trump's less than stellar personal conduct, pastors were able to encourage their congregants to emphasize how successful he was in fulfilling their key "moral" items. For instance, one participant 
emphasized how he believed Trump has made it more acceptable and mainstream for people to say "merry Christmas" to one another. Although this is one minor example it illustrates a much larger point. How pastors helped their congregants navigate such cognitive dissonance was based on what was important to the congregants. For instance, if the congregants felt that certain culture war agenda items (like saying "merry Christmas" or supporting pro-life Supreme Court justices) were more important they would be more likely to reconcile their cognitive dissonance by choosing to support Trump.

Cognitive dissonance also seemed apparent when pastors discussed their identity as leaders. For example, they did not view it as their responsibility to tell their congregants who to vote for; however, they did see themselves as fighters for certain moral imperatives (i.e. a culture where "life flourishes"), and they believed they had a responsibility to teach their congregants how to act responsibly in the public square. Many pastors viewed themselves as conservative evangelicals. They were conservatives in the sense that they held a high view of living by the Scriptures as the inspired Word of God. They wanted to take the text of the Bible as literally as possible and apply it to their lives. In this way they wanted to "conserve" meaning as traditionally applied down through the centuries. The findings of this study stand as an interesting contrast to the findings of Glatz (2012). In that study, it was found that parents adopted more lenient actions in handling their adolescent children's drinking in order to eliminate the dissonance they experienced as a result of their strict attitudes against youth drinking. Perhaps relationship type plays a significant role in the handling of dissonance when there is a power differential.

The other facet of pastors' identity was "evangelical." These participants wanted to be led by their theological convictions about the Bible and be identified as followers of Jesus Christ. However, cognitive dissonance forced them to make imperfect choices in an imperfect world where their convictions could not necessarily be followed without compromise. As self-identifying conservative evangelicals, these pastors needed to make strategic choices. One pastor admitted that Trump was "not a politician" but still was "an instrument of God" in a way that he perhaps did not understand. This could potentially provide a way out of the dissonance. After all, who can see into the mind of God or truly understand the will of God? By putting the Trump agenda into this category, the participant was able to find some peace and reconcile the dissonance. Although Trump might have vulgar characteristics, he was appointed as a leader by God, and there had to be some greater purpose for supporting him. These sorts of thought processes had to be worked out in the mind of pastors as they considered their identity as an evangelical and how that evangelical Christian identity helped them sort out cognitive dissonance.

\section{Limitations}

The study took place in a largely conservative setting with a small sample of evangelical Christian pastors. Perhaps respondents would have addressed the issues at hand differently if they lived in an urban or suburban area. Also, the town in which data was collected has a large Caucasian population. Perhaps a more ethnically or culturally diverse setting would yield different data.

Additionally, the researcher identifies as a member of the evangelical Christian community. This fact might create a bias towards certain ideas or pursuing certain areas of research. If the study had been conducted by a non-evangelical individual, different topics may have been explored. Although familiarity with evangelical language and culture caused the data to be viewed with a specific lens, it also provided the opportunity to explore areas that may have been unfamiliar to non-evangelicals. 


\section{Future Research}

Avenues of future research are abundant. This study took place in a largely rural area where voters tend to hold more conservative political opinions; the data may look very different if collected from more diverse participants. Pastors in large urban areas might conceptualize their identities differently, communicate about political issues with their congregants differently and handle differences between their religious and political opinions differently in such geographical locations. Additionally, future researchers might consider the use of focus groups rather than interviews to assess interactions between individuals with opposing viewpoints. Finally, it would be prudent for researchers to explore other influential religious groups prior to another presidential election.

\section{Conclusion}

Religion can serve as a polarizing and controversial topic, and in recent years has served to create more division. Understanding how evangelical Christian pastors conceptualize religious and political identity and communicate with congregants in handling political and religious differences could help people of all political and religious affiliations understand why religious and political groups experience and create an ingroup/outgroup mentality.

The findings of this study reveal how participants process the relationships and tensions between controversial political and religious issues in the contemporary American political scene. For some Christian pastors, abortion and homosexuality served as the most important concerns, driving them to support Donald Trump's candidacy and presidency amid potential objections. For other pastors, his moral character proved to be too insurmountable of a barrier. Scholars will no doubt examine the unique phenomena of the 2016 election and the Trump presidency for quite some time. Studying evangelical Christians specifically offers a unique set of challenges and opportunities for scholars to gain a deeper understanding of the 2016 election and how it continues to shape the political divide.

\section{Policy Implications}

The findings of this study are relevant to readers in the United States as well as around the world. Evangelical Christians have made a significant mark on right-wing politics in the United States, especially since the 1980s. Additionally, many people in everyday interaction have evangelical beliefs and bring these beliefs into their politics (and vice versa). It is important to understand how these evangelicals navigate the tension between their political identities and religious identities. Church leaders like pastors play a significant role in the lives of these evangelicals. In the United States the political landscape is fractured between conservatives and liberals. The first step to bridging a divide might be understanding. By understanding how evangelicals think and act according to their values and how they navigate conflicting religious and political beliefs to overcome cognitive dissonance, lawmakers might be able to create and govern policy in a more constructive manner.

Although this study has examined the unique phenomenon of American evangelicalism, the broader questions of cognitive dissonance and religious identity are applicable in many contexts. This study might look different if it was conducted amongst Shiite Muslims or Hindus in India. But the underlying issues of how religious leaders attempt to understand and explain religious and political identity and how religious leaders handle conflict between their personal religious and political opinions are also applicable and worthy of being understood in any context. The study 
was conducted with the political and religious tensions of the United States in mind, but religious tension is not exclusive to the United States. This case study serves as a reminder that religious leaders grapple with tension in living out their political and religious beliefs in a pluralistic society. Similar tensions exist in many Western and Eastern cultures. Although this research cannot possibly heal that entire divide, perhaps the case study of evangelical pastors will begin to provide understanding.

The research in this study was also conducted during a controversial period in United States history. During the Trump presidency Americans were confronted with his controversial policies and behavior. Many evangelicals wrestled with how to think about his policy actions and words. Readers of all religious affiliation (or no religious affiliation) can come to this study and understand how religious people think and act when faced with similar controversies. This will hopefully create greater understanding and dialogue amongst different groups in cultures across the world.

\section{Declaration of Interest Statement}

We have no conflicts of interest to disclose.

\section{References}

Addai-Mununkum, R. (2018). Teacher Identity, Positionality and (Mis) Representation of Religion in the Ghanaian School Contexts: Insider/Outsider Case Study Perspectives. American Journal of Qualitative Research, 2(2), 40-59.

Anderton, C. (2011). A review of the religious identity/sexual orientation identity conflict literature: Revisiting Festinger's cognitive dissonance theory. Journal of LGBT Issues in Counseling, 5(3-4), 259-281. https://doi.org/10.1080/15538605.2011.632745

Bagby, R. (1990). A comparative citation analysis of attribution theory and the theory of cognitive dissonance. Personality and Social Psychology Bulletin, 16(2), 274-283. https://doi.org/10.1177/0146167290162008

Boerl, C., \& Donbavand, K. (2015). A God more powerful than yours: American evangelicals, politics, and the internet age. Cambridge Scholars Publishing.

Bolstad, J. (2013). Tactical voting and party preferences: A test of cognitive dissonance theory. Political Behavior, 35(3), 429-452. https://doi.org/10.1007/s11109-012-9205-1

Brown, M. (2018). Donald Trump is not my savior: An evangelical leader speaks his mind about the man he supports as president. Destiny Image Publishers.

Burford, B. (2012). Group processes in medical education: learning from social identity theory. Medical Education, 46(2), 143-152. $\quad$ https://doi.org/10.1111/j.13652923.2011.04099.x

Burns, C. (2006). Cognitive dissonance theory and the induced-compliance paradigm: Concerns for teaching Religious Studies. Teaching Theology \& Religion,9(1), 3-8. https://doi.org/10.1111/j.1467-9647.2006.00255.x

Choi, B. (2017). Construction workers' group norms and personal standards regarding safety behavior: Social Identity Theory perspective. Journal of Management in Engineering, 33(4), 4017001-. https://doi.org/10.1061/(ASCE)ME.1943-5479.0000511

Constantine, G. R. (2017). The Biological Basis of Performativity of Identity-Linking Scientific Evidence to Social Theory. Journal of Ethnic and Cultural Studies, 4(2), 88-95.

Davis, J., Love, T., \& Fares, P. (2019). Collective Social Identity: Synthesizing Identity Theory and Social Identity Theory using digital data. Social Psychology Quarterly, 82(3), 254-273. https://doi.org/10.1177/0190272519851025 
Elo, S. \& Kyngas, H. (2008). The qualitative content analysis process. Journal of Advanced Nursing, 62(1), 107-115 doi: 10.1111/j.1365-2648.2007.04569.x

Fea, J. (2018). Believe me: The evangelical road to Donald Trump. Wm. B. Eerdmans Publishing Co.

Festinger, L. (1957). A theory of cognitive dissonance. Stanford University Press.

Fitzgerald, F. (2017). The evangelicals: The struggle to shape America. Simon \& Schuster.

Glatz, T. (2012). A test of cognitive dissonance theory to explain parents' reactions to youths' alcohol intoxication. Family Relations, 61(4), 629-641. https://doi.org/10.1111/j.17413729.2012.00723.x

Gruber, M. (2003). Cognitive Dissonance Theory and motivation for change: A case study. Gastroenterology Nursing, 26(6), 242-245. https://doi.org/10.1097/00001610200311000-00005

Gundlach, M. (2006). Understanding the relationship between individualism-collectivism and team performance through an integration of social identity theory and the social relations model. Human Relations, 59(12), 1603-1632. https://doi.org/10.1177/0018726706073193

Hankins, B. (2008). American evangelicals a contemporary history of a mainstream religious movement. Rowman \& Littlefield Publishers.

Harris, T. \& Steiner, R.J. (2018). Beyond the veil: A critique of white Christian rhetoric and racism in the age of Trump. Journal of Communication \& Religion, 41, $1 \mathrm{p}$ 33-45.

Heltzel, P. (2009). Jesus and justice: Evangelicals, race, and American politics. Yale University Press.

Hogg, M.A. (1995). A tale of two theories: A critical comparison of Identity Theory with Social Identity Theory. Social Psychology Quarterly, 58(4), 255-269. https://doi.org/10.2307/2787127

Holder, R., \& Josephson, P. (2020). Donald Trump, White Evangelicals, and 2020: a Challenge for American Pluralism. (Author abstract). Society (New Brunswick), 57(5), 540-. https://doi.org/10.1007/s12115-020-00525-z

Lakoff, R.T. (2017). The hollow man: Donald Trump, populism and post-truth politics. Journal of Language \& Politics, 16, 4, p595-605 doi: 10.1075/jlp.17022.lak

Lincoln, S. Y. \& Guba, E. G. (1985). Naturalistic inquiry. Thousand Oaks, CA: Sage.

Long, H. (2016, October 13). Voters say this is the ultimate 'lesser of two evils' election. Retrieved from https://money.cnn.com/2016/09/25/news/economy/donald-trump-hillary-clintonlesser-of-two-evils/index.html

Margolis, M. (2019). Who wants to make America great again? Understanding evangelical support for Donald Trump. Politics and Religion, 1-30. https://doi.org/10.1017/S1755048319000208

Marshden, G (2007) Wayward Christian soldiers: Freeing the gospel from political captivity. Oxford University Press.

Martí, G. (2019). The unexpected orthodoxy of Donald J. Trump: White evangelical support for the 45th President of the United States. Sociology of Religion, 80(1), 1-8. https://doi.org/10.1093/socrel/sry056

Martin, S. (2015). Recession resonance: How evangelical megachurch pastors promoted fiscal conservatism in the aftermath of the 2008 financial crash. Rhetoric \& Public Affairs, 18, p39-77 doi:10.14321/rhetpublaffa.18.1.0039

McGrath, A. (2020). Bringing cognitive dissonance theory into the scholarship of teaching and learning: Topics and questions in need of investigation. Scholarship of Teaching and $\begin{array}{llll}\text { Learning in } & \text { Psychology, 64-90. }\end{array}$ http://dx.doi.org.ezproxy.mnsu.edu/10.1037/st10000168 
Medhurst, M. (2017). The religious rhetoric of anti-Trump evangelicals in the 2016 U.S. Presidential election. Res Rhetorica 2, p1-14.

Miller, D. (2019). The mystery of evangelical Trump support? Constellations, 26(1), 43-58. https://doi.org/10.1111/1467-8675.12351

Monk-Turner, E. (2020). White Evangelical activism and the gender divide in the 2016 Presidential Election. Society (New Brunswick), 57(1), 30-40. https://doi.org/10.1007/s12115-01900438-6

Myers, W. (2019). Following Trump. Theology Today, 76(2), 103-113. https://doi.org/10.1177/0040573619843893

Nicholls, S. B., \& Rice, R. E. (2017). A dual-identity model of responses to deviance in online groups: Integrating Social Identity theory and Expectancy Violations theory. Communication Theory (1050-3293), 27(3), 243-268. https://doiorg.ezproxy.mnsu.edu/10.1111/comt.12113

Onyalla, D. B. (2018). Ethnic Influence of Colleagues and Friends on Choices of News Media Channels: The Case of Catholic Church Leaders in Nairobi, Kenya. Journal of Ethnic and Cultural Studies, 5(2), 140-158.

Reed, J. L. (2019). Religion and politics in the Anglican rhetorical tradition: The rhetoric of John Danforth and the challenge of a political via media. Journal of Communication \& Religion, 42(1), 46-62.

Ribuffo, L. (2006). George W. Bush, the 'faith-based' presidency, and the latest 'evangelical menace'. Journal of American and Canadian Studies, 24, p. 17.

Salek, T. (2014). Faith turns political on the 2012 campaign trail: Mitt Romney, Franklin Graham, and the stigma of nontraditional religions in American politics. Communication Studies, 65(2), 174-188. https://doi.org/10.1080/10510974.2013.851097

Scala, D. (2020). The skeptical faithful: How Trump gained momentum among evangelicals. Presidential Studies Quarterly 50(4).

Smith, D.T. (2016). Predicting acceptance of Mormons as Christians by religion and party identity. Public Opinion Quarterly, 80(3), 783-795. https://doiorg.ezproxy.mnsu.edu/10.1093/poq/nfw022

Strang, S. (2018). God and Donald Trump. Charisma Book Publishers.

Tajfel, H. (1981). Human groups and social categories: Studies in social psychology. Cambridge University Press.

Tajfel, H. (1982). Social identity and intergroup relations. Cambridge University Press.

Vaidis, D. (2019). Respectable challenges to respectable theory: Cognitive dissonance theory requires conceptualization clarification and operational Tools. Frontiers in Psychology, 10, 1189-. https://doi.org/10.3389/fpsyg.2019.01189

Washington, E L. \& Mullainathan, S. (2006). Sticking with your vote: Cognitive dissonance and voting. Cambridge, Mass: National Bureau of Economic Research.

Wengraf, T. (2001). Qualitative research interviewing: Biographic narrative and semi-structured methods. Sage Publishing.

Williams, D. (2018). American Evangelical Politics before the Christian Right. The Journal of Ecclesiastical History, 69(2), 367-372. https://doi.org/10.1017/S0022046917000811 


\section{Notes on Contributors}

Anthony Comer is an adjunct instructor in the Communication Studies department at Minnesota State University, Mankato. His research pursuits include religious rhetoric and political communication. He graduated from Minnesota State University, Mankato with a master's degree in communication studies in December 2019. Before that, he received a bachelor's degree in Ministry from the Antioch School of Church-Planting and Leadership Development in 2016. ORCID ID \# 0000-0001-6611-5263

Laura Jacobi is an Associate Professor in the Communication Studies Department at Minnesota State University, Mankato. Her research pursuits include instructional communication and communication pedagogy. ORCID ID \# 0000-0001-5190-5182

Manuscript received January 4, 2021

Final revision received April 13, 2021

Accepted April 17, 2021 